\title{
EFFICACY OF CERTAIN INSECTICIDES AGAINST RED PALM WEEVIL, Rhynchophorus ferrugineus (OLIVIER) UNDER LABORATORY AND FIELD CONDITIONS. Laila R. A. Elgohary'; A. A. Abd-El-Hady ${ }^{1}$ and F. M. Abd-El-Hady ${ }^{2}$ ${ }^{1}$ Pesticide Dept., Faculty of Agriculture, Mansoura University, Egypt. ${ }^{2}$ Plant Protection Research Institute, Agric. Res. Center, Giza, Egypt.
}

\section{ABSTRACT}

The present work was conducted to evaluate the effect of eight insecticides against red palm weevil (RPW), Rhynchophorus ferrugineus under laboratory and field conditions. The insecticides were studied namely, Chlorpyrifos, Diazinon, Ethion, Fenitrothion, Fipronil, Methomyl, Phenthate and Profenofos. Under laboratory condition results showed that, Chlorpyrifos was the most effective insecticide against the egg stage of RPW, while Fipronil was the most effective one against larval and pupal stage, and Methomyl recorded the highest effect against the adult stages ( $q$, ऊ). At field condition Data revealed that, at the concentration of $3 \mathrm{ml} / \mathrm{L}$, all level of the tested insecticides caused $100 \%$ recovery expect Methomyl which reached $90 \%$ recovery only. Using $2 \mathrm{ml} / \mathrm{L}$ of the tested insecticides revealed $100 \%$ recovery with Fipronil, and $90 \%$ with Chlorpyrifos and Phenthoate, while it was $80 \%$ with Ethion, Fenitrothion and Profenofos. Diazinon and Methomyl revealed only 60 and 50\% recovery, respectively. It worth mentioning that Fipronil seams as the most effective one followed by Chlorpyrifos and Phenthoate.

\section{INTRODUCTION}

The red palm weevil (RPW), Rhynchophorus ferrugineus (Olivier) (Coleoptera: Curculionidae) is one of the most invasive pests causing immense damage to date palms over the world. The RPW is an economically important pest of date palm in many parts of the world. The harmful stage of RPW is the larvae which feeding on the soft tissues of the trunk making tunnels in all direction (Henery, 1917 and Butani, 1975). They penetrate deep in the lower part of the stem causing a lot of damage to the internal tissues. When the infestation is severe, the whole tree falls and dies. Damage symptoms are indicated by the presence of tunnels in the trunk, oozing of thick yellow to brown fluid from the tree, the appearance of chewed up plant tissue in and around openings in the trunk, the presence of a fermented odor from the fluid inside infested tunnels in the trunk, and/or breaking of the trunk or toppling of the crown Kaakeh et al. (2001). The management of RPW was found to be very difficult due to concealed living nature of the pest, all stages live inside tree trunk with symptoms normally appear in the tree only when severe infestation happened, then it is too late to control and prevent the spread of the pest. Insecticides are applied as preventive and curative treatments to limit the spread of weevils Abozuhairah et al. (1996). Injection method by insecticides was considered the best method of controlling the pest (El-Sebaey 2004). The choice of the chemical insecticides for field application is mainly based on the laboratory evaluation of new compounds. The present work aimed to evaluate the effect of eight insecticides against the different stages of RPW (Eggs, larvae, pupae and adults $\hat{\sigma}, q$ ) under Laboratory conditions. Also, evaluation the efficacy of certain insecticides at 
two concentration levels to control this insect at field conditions using the injection method.

\section{MATERIALS AND METHODS}

I- Tested Insecticides:

Common name, trade name, chemical name and formulation of tested insecticides were as follows:-

Table1. Tested insecticides

\begin{tabular}{|c|c|c|c|}
\hline \begin{tabular}{|c|} 
Common \\
name
\end{tabular} & $\begin{array}{l}\text { Trade } \\
\text { name }\end{array}$ & Chemical name & Formulation \\
\hline Chlorpyrifos & $\begin{array}{l}\text { Pyrifos } \\
\text { Al-Nasr }\end{array}$ & $\begin{array}{l}\text { O,O-diethyl O-(3,5,6-trichloro-2-pyridinyl) } \\
\text { phosphorothioate }\end{array}$ & $48 \%$ EC \\
\hline Diazinon & Diazenox & $\begin{array}{c}\mathrm{N}-[[[3,5-\text { dichloro-4-[[3-chloro-5-(trifluoromethyl)- } \\
\text { 2-pyridinyl]oxy] phenyl] amino] carbonyl] }-2,6- \\
\text { difluorobenzamide }\end{array}$ & $60 \%$ EC. \\
\hline Ethion & Indo & $\begin{array}{l}\mathrm{S}, \mathrm{S}^{\prime} \text {-methylene bis }(\mathrm{O}, \mathrm{O}-\text { diethyl }) \\
\text { phosphorodithioate }\end{array}$ & $50 \%$ EC. \\
\hline Fenitrothion & Fenitrothion & $\begin{array}{l}\text { O,O-dimethyl O-(3-methyl-4-nitrophenyl) } \\
\text { phosphorothioate }\end{array}$ & $50 \%$ EC \\
\hline Fipronil & Regent & $\begin{array}{c}\text { 5-amino-[2,6-dichloro-4-(trifluoromethyl)phenyl]- } \\
\text { 4-[(1R,S)- (trifluoromethyl)sulfinyl]-1H-pyrazole- } \\
\text { 3- carbonitrile. }\end{array}$ & $20 \%$ SC \\
\hline Methomyl & Newmyl & $\begin{array}{l}\text { methyl } \mathrm{N}-[[\text { (methylamino)carbonyl]oxy] } \\
\text { ethanimidothioate. }\end{array}$ & $20 \% \mathrm{SL}$ \\
\hline Phenthoate & Phendal & $\begin{array}{c}\text { ethyl } \alpha \text {-(dimethoxyphosphinothioyl) thio] } \\
\text { benzeneacetate }\end{array}$ & $50 \%$ EC \\
\hline Profenofos & Cord & $\begin{array}{l}\text { O-(4-bromo-2-chlorophenyl) O-ethyl S-propyl } \\
\text { Phosphorothioate }\end{array}$ & $72 \%$ EC \\
\hline
\end{tabular}

\section{II- Laboratory experiments:}

These experiments were conducted to evaluate the toxicity effect of eight insecticides against different stages of the red palm weevil, $R$. ferrugineus, a series of concentrations (in water) for each insecticide was calculated as the active ingredient (a.i) based on ppm by diluting the commercial formulation.

\section{A- $\quad$ Red palm weevil, R. ferrugineus, culture :}

Laboratory culture of RPW $R$. ferrugineus maintained under the constant temperature and humidity of $29 \pm 1^{\circ} \mathrm{C}$ and $85 \pm 5 \%$ R.H., according to (Mesallam, 2010) till the time of study. 


\section{B-Treatments:}

\section{1- Egg treatment:}

One day old eggs were dipped in the prepared solutions for 10 Seconds, using 25 eggs for each insecticide concentration (presented by 5 replicates). Each replicate contained 5 eggs. The eggs were placed on a relatively small perforated plastic cover that based on the inner lid of cylindrical plastic box $(9.5 \times 5.0 \mathrm{~cm}$. in diameter and depth) which filled with $50 \mathrm{ml}$. of distilled water. Then, the box was tightly covered with imperforated cover to allow a relative humidity of about $90 \%$ in order to obtain high percentage of eggs hatchability. The untreated eggs were dipped in water as check. Eggs for each treatment were kept for 8 day under observation at $29 \pm$ $1{ }^{\circ} \mathrm{C}$ and $85 \pm 5 \%$ R.H. These eggs were inspected daily to record the duration of egg stage as well as hatchability percentages. The number of hatched eggs were counted and hatchability percentage was calculated based on (Finny 1971).

\section{2- Larval treatment:}

Small pealed cylindrical pieces of sugarcane $(5 \mathrm{~cm})$ were dipped in the prepared solutions for 10 seconds then allowed to dry in air for 2 hours. Treated pieces were transferred to a cylindrical plastic box $(9.5 \times 5.0 \mathrm{~cm}$. in diameter and depth) and tightly covered with a perforated cover. Fifth and tenth instar larvae were introduced into the box (one larval/box), using 15 larvae for each insecticide concentration (presented by 5 replicates). Each replicate contained 3 larvae. Mortality records were taken after $48 \mathrm{~h}$. mortality Percentage was calculated based on (Finny 1971).

\section{3- Pupal stage:-}

Newly formed pupae were dipped in the prepared solutions for 10 seconds then allowed to dry in air for $24 \mathrm{~h}$. using 15 pupae for each insecticide concentration (presented by 5 replicates). Each replicate contained 3 pupae. The pupae were transferred to cylindrical plastic box (9.5 $\times 5.0 \mathrm{~cm}$. in diameter and depth) and tightly covered with a perforated cover. The pupae were introduced into the box (one pupa/box); and percentage of pupae emergence, mortality were recorded after 4 weeks. Mortality percentage was calculated based on (Finny 1971).

\section{4- Adult stage:}

Small pealed cylindrical pieces of sugarcane stem $5 \mathrm{~cm}$ were dipped in the prepared solutions for 10 seconds then allowed drying in air for $2 \mathrm{~h}$. using 20 insects for each insecticide concentration (presented by 5 replicates). Each replicate contained two boxes. Each box contained one male and one female. Pieces of sugarcane stem were transferred in a cylindrical Plastic box $(9.5 \times 5.0 \mathrm{~cm}$. in diameter and depth) and tightly covered with a perforated plastic cover. Female and male were introduced into plastic box, mortality was recorded after 24 and $48 \mathrm{~h}$. Percent mortality was calculated based on (Finny 1971).

\section{III- Field experiment:}

These experiments were carried out at Belbis district, Sharkia Governorate, Egypt, during March to November 2010 to evaluate the efficacy of two different concentrations $0.2 \%$ and $0.3 \%$ of certain eight insecticides for 
controlling $R$. ferrugineus using the injection method. The injection method were used as followed, the insecticide solution was injected in 7-15 holes covered the infested area of palm trunk inside and around till reached the uninfected tissues (solid tissues), and the holes were sealed with cement or mud. Ten moderately infested date palms 10-15 years old were used for each treatment. All data concerning insecticides name, number of replicate, number of holes and date of treatment were recorded. After two weeks, the injected palm trees were observed and the recovered ones were recorded. Stop or limited, odorless oozing and drying of the infected site were taken as an indication of effectiveness of the insecticide for control RPW.

\section{RESULTS AND DISCUSSION}

\section{I- Laboratory experiments:}

1- Effect of tested insecticides against the one day egg stage of red palm weevil, $R$. ferrugineus:

The effect of tested insecticides against the one day egg stage of red palm weevil, $R$. ferrugineus was presented in Table (2). Data showed that, Chlorpyrifos was the highest effective insecticides followed by, Fipronil, Ethion, Profenofos, Methomyl, Fenitrothion, Diazinon, and the least one was Phenthoate with toxicity index of $85.1,64.3,52.3,48.0,33.5,32.2$ and $13.1 \%$, respectively based on $\mathrm{LC}_{50}$ of Chlorpyrifos $100 \%$. The $\mathrm{LC}_{50}$ for these insecticides ranged from $82.0 \mathrm{ppm}$ for Chlorpyrifos to $624.4 \mathrm{ppm}$ for Phenthoate

2- Effect of tested insecticides against the fifth and tenth larval stage of red palm weevil, $R$. ferrugineus:

The present data in Table (2) showed that concerning the fifth larval instar, data clearly indicated that, Fipronil was the highest effective insecticides after $48 \mathrm{hrs}$. of exposure followed by, Phenthoate, Methomyl, Fenitrothion, Chlorpyrifos, Ethion, Profenofos, Diazinon, with toxicity index of $30.8,24.0,18.9,18.7,18.1,17.6$ and $17.2 \%$ based on $L_{50}$ of Fipronil $100 \%$, respectively. In the case of tenth larval instar, data revealed that, Fipronil was the highest effective insecticides against the tenth larval instar of $R$. ferrugineus after 48 hrs of exposure followed by Phenthoate, Methomyl, Fenitrothion, Chlorpyrifos, Ethion, Profenofos and Diazinon. Their toxicity index were $51.9,48.7,47.7,39.4,39.1,29.3$ and $23.4 \%$, respectively based on $\mathrm{LC}_{50}$ of Fipronil as $100 \%$.

3- Effect of tested insecticides against the pupal stage of red palm weevil, $R$. ferrugineus:

Data in Table (2) revealed that, Fipronil was the highest effective insecticides against pupal stage of $R$. ferrugineus after four weeks of exposure followed by Methomyl, Phenthoate, Ethion, Chlorpyrifos, Fenitrothion, Diazinon, and the least one was Profenofos. Their toxicity index were $39.9,38.8,34.4,33.5,33.4,26.5$ and $22.7 \%$, respectively based on $\mathrm{LC}_{50}$ of Fipronil as $100 \%$. 


\section{4- Effect of tested insecticides against the adult stage of red palm weevil, $R$. ferrugineus: \\ A- Effect on female:}

Table (3) showed that, the effect of tested insecticides against the female of adult stage of $R$. ferrugineus after 24 and $48 \mathrm{hrs}$ of exposure. Data revealed that, Methomyl was the highest effective insecticides against the female of adult stage after $24 \mathrm{hrs}$ of exposure followed by Fipronil, Phenthoate, Chlorpyrifos, Fenitrothion, Profenofos, Ethion, and the least one was Diazinon. Their toxicity index were 85.8, 48.1, 42.4, 42.3, 41.3, 33.1 and $29.3 \%$, respectively based on LC $_{50}$ of Methomyl $100 \%$. Also after $48 \mathrm{hrs}$ of exposure Methomyl was the highest effective insecticides against the female of adult stage followed by Fipronil, Diazinon, Ethion, Profenofos, Chlorpyrifos, Phenthoate and the least was Fenitrothion, with toxicity index of 32.4, 27.1, $15.1,13.3,13.2,12.6$ and $7.6 \%$, respectively based on $L^{2} C_{50}$ of Methomyl $100 \%$.

\section{B- Effect on male:}

Data in Table (3) revealed that, Methomyl was the highest effective insecticides against the male of adult stage of $R$. ferrugineus after $24 \mathrm{hrs}$ of exposure followed by Ethion, Chlorpyrifos, Diazinon, Fipronil, Profenofos, Fenitrothion, and the least one was Phenthoate, with toxicity index of 46.0, $42.8,39.7,39.4,31.5,30.1$ and $29.2 \%$, respectively based on LC $_{50}$ Methomyl $100 \%$. Also Methomyl was the highest effective insecticides against the male of adult stage of $R$. ferrugineus after $48 \mathrm{hrs}$ of exposure followed by Ethion, Fipronil, Diazinon, Phenthoate, Fenitrothion, Chlorpyrifos and the least one was Profenofos. Their toxicity index were 41.7, 37.0, 35.6, 27.6, 15.6, 14.7 and $13.5 \%$, respectively based on $\mathrm{LC}_{50}$ of Methomyl $100 \%$.

Blockage of insect embryonic development has been reported to occur when the insecticide is applied directly to the egg stage soon after oviposition Kathuria et al (2000) and when it is applied to the female during egg formation Reissig et al (1998), or at maturation Ahmed et al (1990). Barranco et al. (1998) evaluated some pesticides against 7 days and 1 month old larvae and found that, Fipronil caused $100 \%$ mortality for 7 days larvae at 0.1 $\mathrm{ppm}$ and caused $100 \%$ mortality for 1 month larvae at $0.2 \mathrm{ppm}$. Abraham and Vidyasagar (1992) reported that insecticides such as chlorpyrifos, endosulfan and methiothion at $0.1 \%$ could be recommended for RPW. In addition, Abraham et al. (1975) evaluated seven insecticides for controlling RPW. They reported that dichlorvos at $0.25 \%$, methyl-O-demeton, phosphamidon and arprocarb at $0.5 \%$, trichlorphon, malathion at $1.0 \%$ and parathion at $2.0 \%$ gave $100 \%$ mortality on the seventh day. Ajlann et al. (2000) evaluated five organophosphorus insecticides viz.; pirimiphos-methyl, chlorpyrifosfenitrothion, trichlorphon and oxydemeton methyl against the larvae and adult stage of both male and female of $R$. ferrugineus, and found that, pirimiphosmethyl was the most potent against males and female whereas, chlorpyrifos was the least one in this respect. Oxydemeton methyl recorded the highest activity against the larvae. Abbas (2005) evaluated four insecticides against eggs, larvae and adults stages of $R$.ferrugineus under laboratory conditions and found that profenofos proved to be the most potent compound followed 
by emamectin, abamectin and lufenuron especially against one and two days old egg stage. El Ezaby (1997) reported that insecticides such as Carbosulfan, Pirimiphos ethyle and Dimethoate $11 \%+$ Phenthoate $41 \%$ in Laboratory tests resulted in $80-100 \%, 90 \%$ and $100 \%$ mortality of the adults, pupae and larvae, respectively.

The choice of the chemical insecticides for field application is mainly based on the laboratory evaluation of certain insecticides. Accordingly, our findings indicated that Chlorpyrifos was the most effective insecticide against the egg stage of RPW, Fipronil was the most effective one against larval and pupal stage, and Methomyl recorded the highest effect against the adult stages $(\not, \hat{\jmath})$.

\section{III- Field experiment:}

The effect of tested insecticides at two concentrations levels against the red palm weevil, $R$. ferrugineus (Olivier) using the injection method was presented in Table (4). Data showed that, using the tested insecticides at concentration of $3 \mathrm{ml} / \mathrm{L}$ caused $100 \%$ recovery expect for Methomyl which reached $90 \%$ recovery only. While, using $2 \mathrm{ml} / \mathrm{L}$ of Fipronil revealed $100 \%$ recovery. Chlorpyrifos and Phenthoate revealed $90 \%$ recovery. Ethion, Fenitrothion and Profenofos revealed $80 \%$ recovery. Diazinon, and Methomyl revealed 60 and $50 \%$ recovery, respectively. It worth mentioning that Fipronil seams as the most effective one followed by Chlorpyrifos and Phenthoate. Methomyl seems to be the least effective one against RPW which revealed 90 and $50 \%$ recovery at the concentration of 3 and $2 \mathrm{ml} / \mathrm{L}$, respectively.

In the present study, eight different insecticides were applied through trunk injection to control RPW infestation on date palm. Injection method of different insecticides is an effective control method to control RPW attack as reported by Lepesme 1974; Nirula 1956; Mathen and Kurian, 1966 and 1967. Abbas (2013) found that Chemical application by injection gave more than $85 \%$ positive results and recovery for the trees. Shar et al (2012) found that Fipronil caused recovered (33\%), while Chlorpyrifos caused $(26 \%)$ recovery of the infested date palm trees. Many scientists have suggested that injection of different insecticides can control RPW attack very well (Frohlich and Rodewald, 1970; Laksbmanan et al, 1972; Rao et al., 1973). Ajlann et al. (2000) tested five organophosphorus insecticides against RPW and observed that pirimiphos-methyl at $0.2 \%$ or oxydemeton-methyl at $0.36 \%$ was enough to destroy the larvae and adults of RPW within three days period. Similarly, Khalifa et al. (2001) found that the insecticidal injection of carbosulfan, phenthoate+dimethoate, dimethoate+endosulfan and phostoxin tablets have significantly reduced the infestation of RPW in the field. 
J. Plant Prot. and Path., Mansoura Univ., Vol.6 (1), January, 2015 
Laila R. A. Elgohary. et al.

Table 4: the effect of field application of tested insecticides at two concentrations levels against the red palm weevil, $R$. ferrugineus (Olivier) using the injection method.

\begin{tabular}{|l|c|c|}
\hline \multicolumn{1}{|c|}{ Treatments } & $\begin{array}{c}\text { Concentration } \\
\text { mI/liter }\end{array}$ & $\begin{array}{c}\text { Percentage of } \\
\text { recovery }\end{array}$ \\
\hline Chlorpyrifos & 3 & 100 \\
\multirow{2}{*}{ Diazinon } & 2 & 90 \\
\hline \multirow{2}{*}{ Ethion } & 3 & 100 \\
& 2 & 60 \\
\hline \multirow{2}{*}{ Fenitrothion } & 3 & 100 \\
& 2 & 80 \\
\hline Fipronil & 3 & 100 \\
& 2 & 80 \\
\hline \multirow{2}{*}{ Methomyl } & 3 & 100 \\
& 2 & 100 \\
\hline \multirow{2}{*}{ Phenthoate } & 3 & 90 \\
& 2 & 50 \\
\hline \multirow{2}{*}{ Profenofos } & 3 & 100 \\
& 2 & 90 \\
\hline
\end{tabular}

\section{REFERENCES}

Abbas, M.K. (2013). Evaluation methods for red palm weevil control in Egypt during (1992-2010) AFPP - palm pest mediterranean conference Nice, France - 16, 17 and 18 January 2013, PP 369-386.

Abbas, M. K. (2005). Integrated management for controlling red palm weevil. Ph.D. Thesis, Fac. of Agric., Ain Shams Univ.; 142 pp.

Abozuhairah, R.A.; P.S., Vidyasagar and V.A., Abraham (1996). Integrated pest management of red palm weevil Rhynchophorus ferrugineus (Olivier), in: Date Palm Plantations of the Kingdome of Saudi Arbia, Proceedings, XX International Congress of Entomology, Firenze, Italy, Aug. 25-31, p. 541.

Abraham, V.A.; K.M., koya and C., Kurian (1975). Evaluation of seven insecticides for control of red palm weevil, Rhynchophorus ferrugineus, J. Plant Crops 3: 71-72.

Abraham, V.A. and P.S., Vidyasagar (1992). Strategy for Control of Red Palm Weevil of Date Palm in the Kingdom of Saudi Arabia, Consultancy report Submitted to the Ministry of Agriculture and Water, Kingdom of Saudi Arabia, p.36.

Ahmed K; N.H., Rao and A.S., Reddy (1990). Ovicidal action of insecticides on eggs of gram pod borer (Heliothis armigera), Indian J. Agric. Sci. 60: 154-156. 
Ajlann A.M.; M.S., Shawir; M.M., Abo El-Saad; M.M., Rezk and K.S., Abdulslam (2000). Laboratory evaluation of certain organophosphorus insecticides against the red palm weevil, $R$. ferrugineus (Oliver). Scient. J. King Faisal Univ., (1): 15-16.

Barranco, P.; J., pena; M. M., Martin; T., Cobello and J., Peno (1998). Efficiency of chemical control of the new palm pest Rhynchophorus ferrugineus (Olivier (Col.: Curculionidae). Boletin de Sanidad Vegetal Plagas, 24 (2): 301-306.

Butani, D. K. (1975). Insect pests of crops and their control. Date palm pesticides. 9(3): 40-42 India.

El Ezaby, F. A. (1997). Injection as method to control the Red Indian date Palm weevil, Phynchophorus ferrugineus - Arab J. Plant Prot. 15 (1): 31- 38.

El-Sebaey, Y. (2004). Field evaluation of certain insecticides against red palm weevil Rhynchophorus ferrugineus Oliv. (Coleoptera: Curculionidae) in Egypt. Egyptian J. Agric. Res., 82(4): 1591-1598.

Finney D.J. (1971): Probit analysis. A Statistical Treatment of the Sigmoid Response Curve. 7th Ed., Cambridge Univ. Press, England.

Frohlich, G. and J.W., Rodewald (1970). Pests and Diseases of Tropical Crops and their Control. Oxford, New York, pp. 1-99.

Henery, G. M. (1917). The coconut red palm weevil, Rhynchophorus ferrugineus Trop. Agric., Pradeniya, xlvii, no.4: 218-219.

Kaakeh,W.; A., Khamis and M., Aboul-Nour (2001). The Red Palm Weevil: The Most Dangerous Agricultural Pest, UAE University, p. 163.

Kathuria, V.; P., Ram and R.K., Saini (2000). Susceptibility of Heliothis armigera (Hübner) eggs to different insecticides, J. Entomol. Res. 24:213-217

Khalifa, O.; A.H., El Assal; F.A.A., Ezaby; M.A., Murse; S.M., Al Nuaimi and N.S., Al-Zehli (2001). Database for infestation of date palm by red palm weevil (Rhynchophorus ferrugineus oliver) In U.A.E. and Oman. 2nd International Conf. on Date Palms (al-Ain, UAE), pp. 25-27.

Lakshmanan, P.L.; P.B., Subba-Rao and T.R., Subramanian (1972). A note on the control of the coconut red palm weevil Rhynchophorus ferrugineus with certain new chemicals - Madras Agric. J., 59(11/12): 638-639 (la: 7508)

Lepesme, P. (1974). Les insects des palmires lechevalier, Paris; p. 454.

Mathen, K. and C., Kurian (1966). Prophylactic control of R. ferrugineus. Indian J. Agric. Sci., 36: 285-286.

Mathen, K. and C., Kurian (1967). Insecticidal trials against Rhynchophorus ferrugineus, the coconut weevil. Indian J. Agric. Sci., 37: 231-235.

Mesallam, T. (2010). Effect of different date palm varieties on some biological aspects of the Red Palm Weevil, R. ferrugineus (Olivier) and its control. Ph. D. Thesis, ac. of Agric., Zagazig University. 271pp.

Nirula, K.K. (1956). Investigations on the pests of coconut palm - part IV Rhynchophorus ferrugineus F. Indian Cocon. J., 10: 28-44.

Rao, P.V.S.; T.R., Subramaniam and E.V., Abraham (1973). Control of the red palm weevil on coconut. J. Plantation Crops, 1: 26-27. 
Reissig, W.H.; J.P., Nyrop and R., Straub (1998). Oviposition model for timing insecticide sprays against plum curculio (Coleoptera: Curculionidae) in New York State, Environmental Entomology 27: 1053-1061.

Shar, M. U.; M. A., Rustamani; S. M., Nizamani and L. A., Bhutto (2012). Red palm weevil (Rhynchophorus ferrugineus Olivier) infestation and its chemical control in Sindh province of Pakistan. African Journal of Agricultural Research Vol. 7(11), pp. 1666-1673, 19 March, 2012.

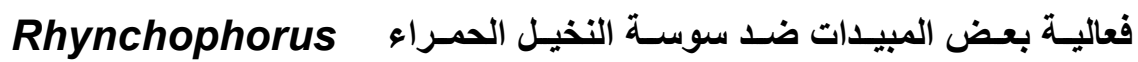
ferrugineus Olivier

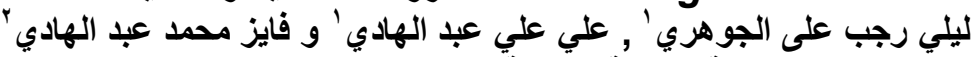

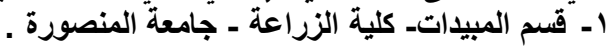
r - معهد بحوث وقاية النباتات ـ مركز البحوث الزئة الزراعية ـ الجيزة ـ الاقي ـ مصر.

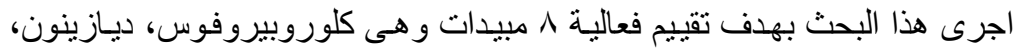

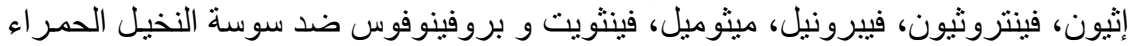
Rhynchophorus ferrugineus Olivier نتائج التجارب المعملية أن مبيد كلوروبيروفوس كان اكثر فعالية تجاه طور البيضة بينما كان

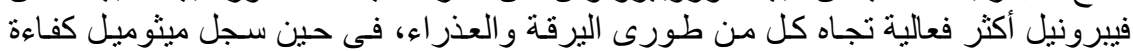

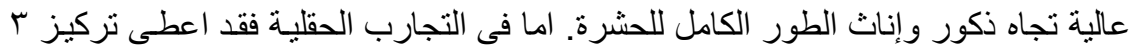

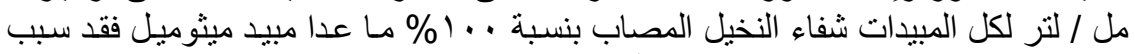

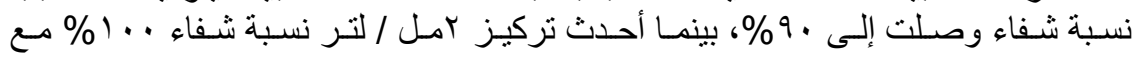

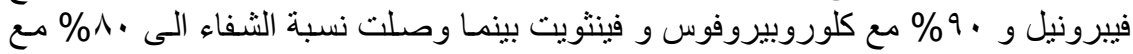

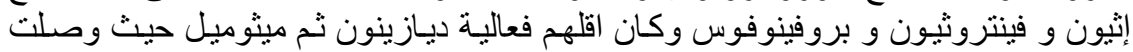

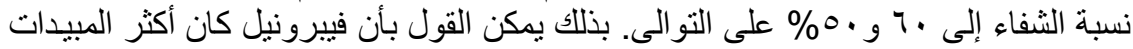
فعالية يليه كلوروبيروفوس و فينتويت. 


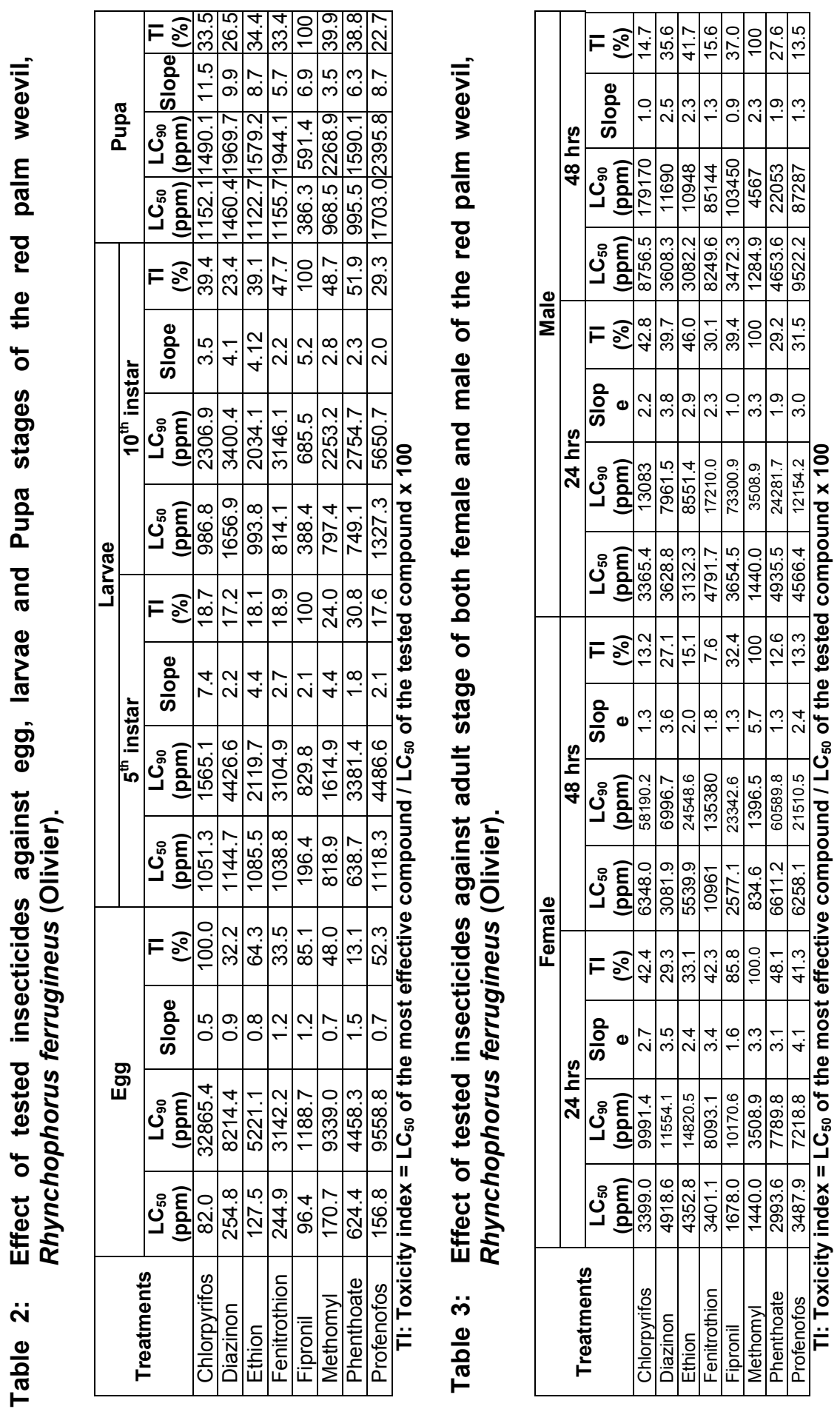

